www.jmscr.igmpublication.org

Impact Factor (SJIF): 6.379

Index Copernicus Value: 79.54

ISSN (e)-2347-176x ISSN (p) 2455-0450

crossrefDOI: https://dx.doi.org/10.18535/jmscr/v6i8.197

Journal Of Medical Science And Clinical Research

IGM Publication

An Official Publication of IGM Publication

\title{
Observation of Bilirubin Pattern and Incidence of Cholelithiasis in Sickle Cell Disease in Children: A Hospital Based Study
}

\author{
Authors \\ Dilip Kumar $^{1 *}$, Rajeeva Mishra ${ }^{2}$, Gora Chand ${ }^{3}$, Akhilesh Kumar ${ }^{4}$, Sweety Kumari ${ }^{5}$ \\ ${ }^{1}$ Junior Resident, Department of Paediatrics and Neonatology, RIMS, Ranchi \\ ${ }^{2}$ Professor, Department of Paediatrics and Neonatology, RIMS, Ranchi \\ ${ }^{3}$ Junior Resident, Department of Paediatrics and Neonatology, RIMS, Ranchi \\ ${ }^{4}$ Junior Resident, Department of Pharmacology, RIMS, Ranchi \\ ${ }^{5}$ Junior Resident, Department of Obstetrics and Gynaecology, RIMS, Ranchi \\ *Corresponding Author
}

\section{Dilip Kumar}

Junior Resident, Department of Paediatrics and Neonatology, RIMS, Ranchi, India

Email:dr.diliprims@gmail.com, Mobile no: 7070434160

\section{Abstract}

Background: Sickle cell disease has been reported from all over the world including India. The early detection of high bilirubin pattern and cholelithiasis \& their treatment is essential for improving quality of life in sickle cell disease children.

Objective: Current study aims at evaluating bilirubin pattern and incidence of cholelithiasis in cases of sickle cell disease in paediatric population attending RIMS, Ranchi.

Materials \& Method: 56 consecutive cases admitted to hospital with sickle cell disease were studied by history, thorough examination \& stepwise investigations including CBC with PBS, Liver function tests inclu. Serum bilirubin \& ultrasonography of whole abdomen.

Results: The fever, abdominal pain, tiredness, cough, bone pain, vomiting, headache and chest pain had been noted in $85.7 \%$ (48 cases), 33.9\% (19 cases), 28.5\% (16 cases), 23.2\% (13 cases),23.2\% (13 cases), $7.1 \%$ (4 cases), $1.7 \%$ (1 case) and $1.7 \%$ (1 case) of sickle cell disease patients respectively but no leg ulcer, priapism or stroke. Most of the patients were males (M:F ratio of 1.95:1), hindu religion(67.9\%) \& tribals (59\%). The reticulocyte count was high (mean 6.67) in all patients and haemoglobin ranged between 4.8-9 $\mathrm{gm} / \mathrm{dl}$ which was low. Hepatomegaly was present in all cases while 2 patients had splenectomy previously and another 3 patients had no palpable spleen. Patients with gallbladder abnormality in the form of stone or sludge had higher total and direct fraction of serum bilirubin as well as serum transaminases. The overall incidence of cholelithiasis was $7.14 \%$. The incidence of gallstone increases with increase in age.

Conclusion: There is an increasing incidence of gallstone as well as gallbladder sludge with increasing age among sickle cell disease patients but no difference in earlier age group.

Keywords: Sickle cell hepatopathy, cholelithiasis.

\section{Introduction}

Sickle cell disease has been reported from all over the world including India. According to a study conducted by the Jharkhand health department, > 9 lakh tribals are suffering from the fatal sickle cell disease. This accounts for $10 \%$ of the state's 
total tribal population as per the 2011 census, right next to Chhattisgarh (10 lakh) as the worst- hit state, and ahead of Odisha $(6 \text { lakh })^{[1]}$. A well known complication in these cases is right upper quadrant syndrome manifested by hyperbilirubinaemia, abdominal pain, fever, right upper quadrant tenderness, hepatomegaly, abnormalities of liver function test and hepatic failure. Possible causes include cholelithiasis, viral hepatitis, biliary cirrhosis and hepatic ischaemia. So this study was an attempt to evaluate the hepatobiliary dysfunction in cases of sickle cell anaemia in children.

\section{Methods}

This study was a hospital based prospective cross sectional study conducted from June 2016 to May 2017 in the Department of Paediatrics and Neonatology, Rajendra Institute of Medical Sciences, Ranchi. In this study, 56 confirmed cases of Sickle cell disease diagnosed on the basis of Sickling test or HPLC \{High Performance Liquid Chromatography) of age group 1 to 18 years were included for assessment of their hepatobiliary profile and its clinical correlation. The same functions have also been carried out in 20 control children.

Exclusion criteria included -

1. Children $<1$ year and $>18$ years of age.

2. Haemoglobinopathies other than sickle cell disease.

3. Children with viral hepatitis.

4. Children with known cholestatic liver disorders.

Investigations included -

1. Serum bilirubin estimation,

2. Test for bile pigment in urine,

3. Test for urobilinogen in urine,

4. SGOT/SGPT/Alkaline phosphatase estimation,

5. Ultrasonography of abdomen $\rightarrow$ It is an ideal means of investigating hepatobiliary axis. The USG criteria adopted for diagnosis are shown in table 1. Categories 1 and 2 are positive indicators of gallstones; Category 3 is defined as biliary sludge.

\section{Observations}

1. Out of 56 enrolled sickle cell disease patient in our study -

$>$ Sex $\rightarrow$ Males 37 (66.1\%) \& Females 19 $(33.9 \%)$ with male: female ratio of 1.95 : 1.

$>$ Religion $\rightarrow$ Hindu 38 (67.9\%), Muslim 15 (26.8\%) \& Christian 3 (5.4\%).

$>$ Race $\rightarrow$ Tribal 33 (58.9\%) \& Non tribal $23(41.1 \%)$.

$>$ Family history $\rightarrow$ Present 8 (14.3\%) \& Absent 48 (85.7\%).

2. Distribution of

$>$ Symptoms of patients shown in Table 2.

$>$ Blood indices shown in Table 3.

$>$ Hepatosplenomegaly shown in Table 4.

$>$ Gallbladder abnormality in different age groups shown in Table 5.

$>$ Hepatic enzymes and serum bilirubin shown in Table $6 \rightarrow$ Mean AST (50.57), ALT (50.52), Total serum bilirubin (3.31) and Direct serum bilirubin (0.89) which were higher than normal showing that the patients in our study had some hepatobiliary dysfunction.

3. Relation of bilirubin pattern with gallbladder pathology shown in Table 7.

Table 1: USG criteria adopted for diagnosis.

\begin{tabular}{|l|l|}
\hline $\begin{array}{l}\text { Cate } \\
\text { gory }\end{array}$ & Criteria \\
\hline 1 & $\begin{array}{l}\text { Presence of shadowing opacities that move with } \\
\text { gravity within a well defined gallbladder lumen. }\end{array}$ \\
\hline 2 & $\begin{array}{l}\text { Non visualisation of the gallbladder lumen, often } \\
\text { with high level echoes and shadowing in the area } \\
\text { of gallbladder fossa. }\end{array}$ \\
\hline 3 & Non shadowing opacities in the gallbladder lumen \\
\hline 4 & Normal ultrasound examination \\
\hline
\end{tabular}


Table 2: Distribution of Symptoms of patients

\begin{tabular}{|l|c|c|}
\hline Symptoms & Number & Percentage \\
\hline Fever & 48 & 85.7 \\
\hline Abdominal pain & 19 & 33.9 \\
\hline Tiredness & 16 & 28.5 \\
\hline Cough & 13 & 23.2 \\
\hline Bone pain & 13 & 23.2 \\
\hline Vomiting & 4 & 7.1 \\
\hline Headache & 1 & 1.7 \\
\hline Chest pain & 1 & 1.7 \\
\hline Leg ulcer, Priapism or Stroke & 0 & 0 \\
\hline
\end{tabular}

Table 3: Distribution of Blood indices

\begin{tabular}{|l|c|c|c|c|}
\hline Indices & Maximum & Minimum & Mean & Standard deviation \\
\hline Reticulocytes count \% & 9.5 & 3.4 & 6.67 & 1.4 \\
\hline Haemoglobin \% & 9 & 4.8 & 7.02 & 1.04 \\
\hline
\end{tabular}

Table 4: Distribution of Hepatosplenomegaly.

\begin{tabular}{|l|c|c|c|c|c|}
\hline Variable & No. of patients & Maximum size in $\mathrm{cm}$ & Minimum size in $\mathrm{cm}$ & Mean & Standard deviation \\
\hline Hepatomegaly & 56 & 8 & 2 & 3.26 & 1.07 \\
\hline Splenomegaly & 51 & 7 & 0 & 3.3 & 1.61 \\
\hline
\end{tabular}

Table 5: Distribution of Gallbladder abnormality in different age groups

\begin{tabular}{|l|c|c|c|}
\hline Age group & Total number of patients & Patients with gallstone & Patients with gallbladder sludge \\
\hline $1-6$ years & 18 & 0 & 0 \\
\hline $7-12$ years & 29 & $1(3.45 \%)$ & $3(10.34 \%)$ \\
\hline $13-18$ years & 9 & $3(33.33 \%)$ & $3(33.33 \%)$ \\
\hline
\end{tabular}

Table 6: Distribution of Hepatic enzymes and serum bilirubin

\begin{tabular}{|l|c|c|c|c|}
\hline Variables & Maximum & Minimum & Mean & Standard deviation \\
\hline SGOT / AST & 108 & 28 & 50.57 & 15.30 \\
\hline SGPT / ALT & 104 & 34 & 50.52 & 13.94 \\
\hline ALP & 780 & 128 & 273.57 & 133.57 \\
\hline Serum bilirubin T. & 8.3 & 1.4 & 3.31 & 1.29 \\
\hline Serum bilirubin D. & 4.8 & 0.2 & 0.89 & 0.95 \\
\hline
\end{tabular}

Table 7: Relation of bilirubin pattern with gallbladder pathology.

\begin{tabular}{|l|c|c|c|}
\hline Variables & Patients with gallstones & Patients with gallbladder sludge & Others \\
\hline Mean of total serum bilirubin $(\mathrm{mg} / \mathrm{dl})$ & 6.2 & 4.1 & 2.9 \\
\hline Mean of direct serum bilirubin $(\mathrm{mg} / \mathrm{dl})$ & 3.1 & 1.4 & 0.6 \\
\hline
\end{tabular}

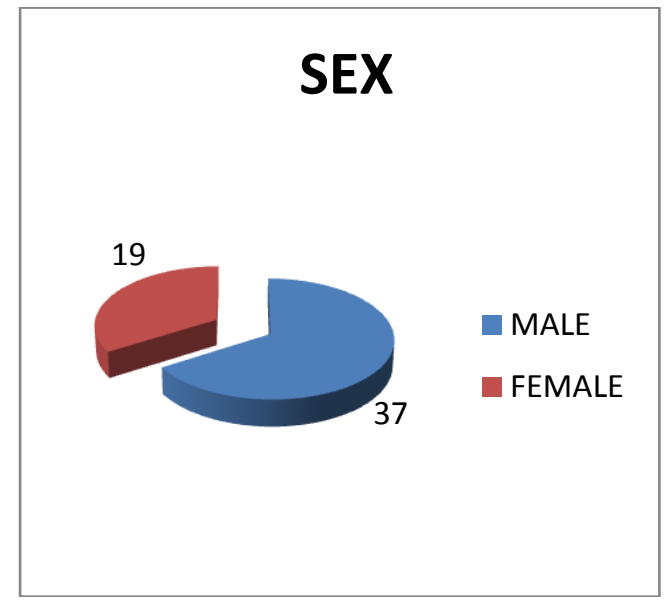

Fig 1 : Sex Distribution

\section{RELIGION}

3

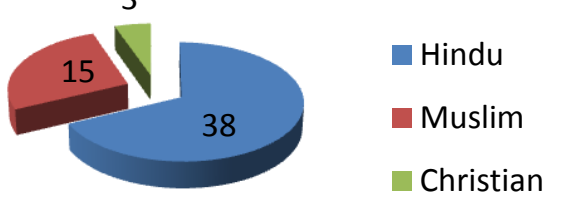

Fig 2 : Religious Distribution 


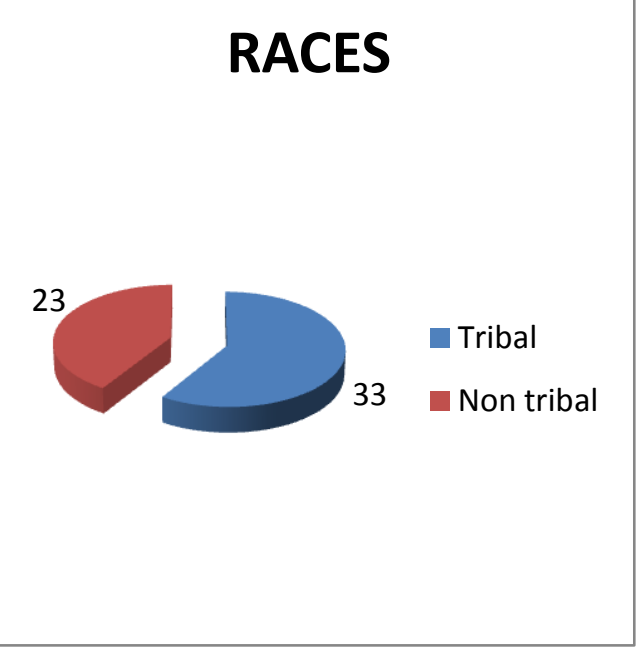

Fig 3 : Racial Distribution

\section{FAMILY HISTORY}

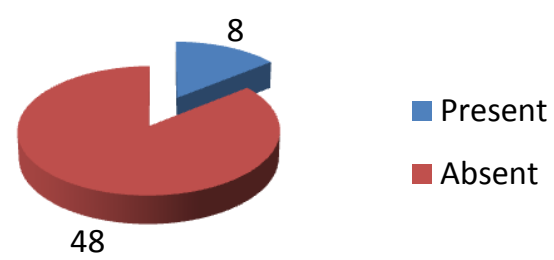

Fig 4 : Distribution of Family history

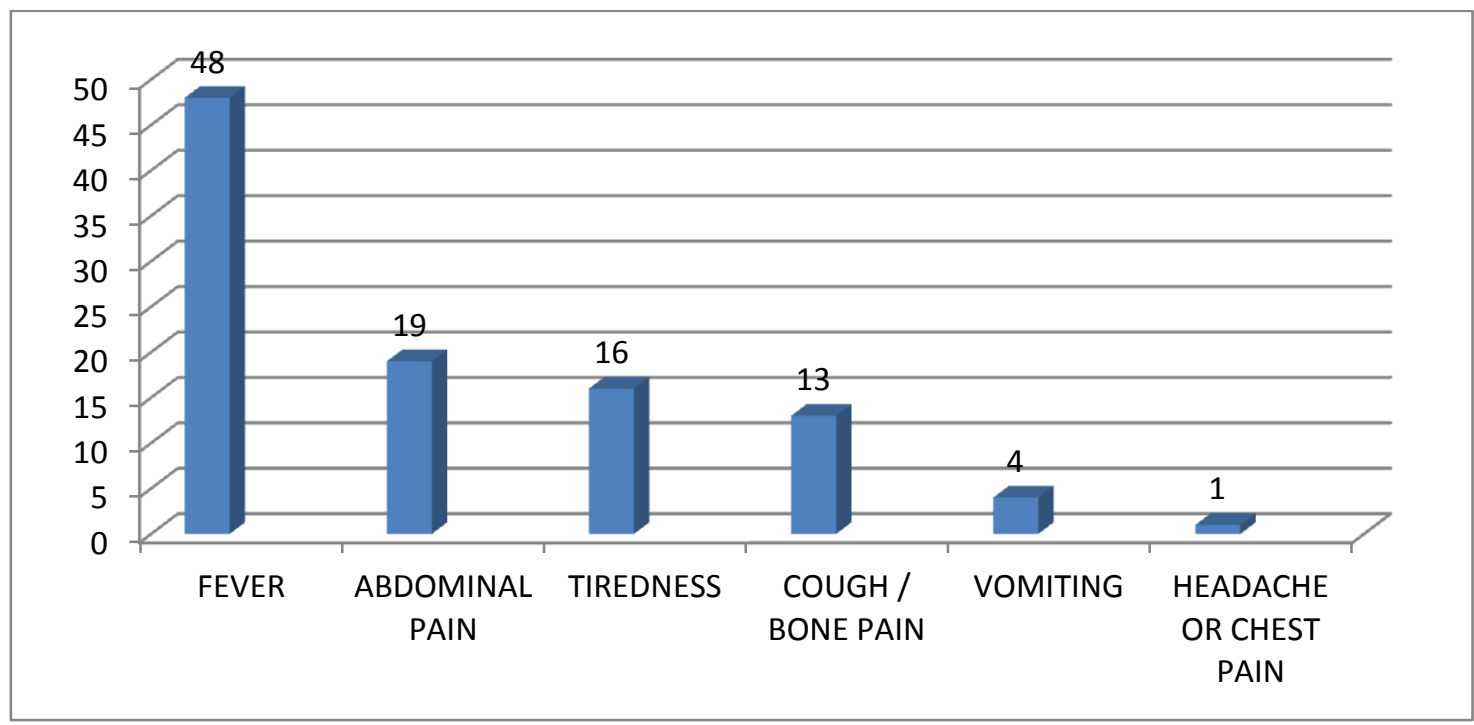

Fig 5 : Symptomatic Distribution

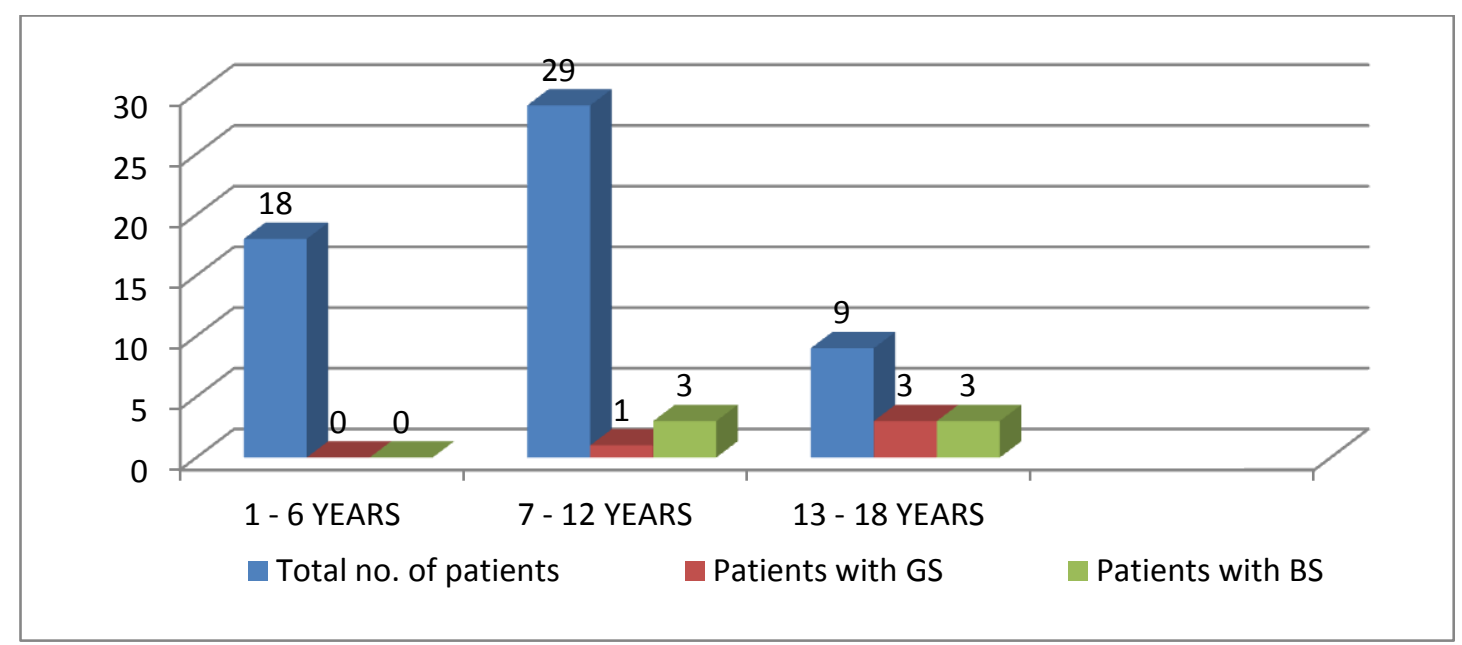

Fig 6 : Distribution of gallbladder abnormality in different age groups 


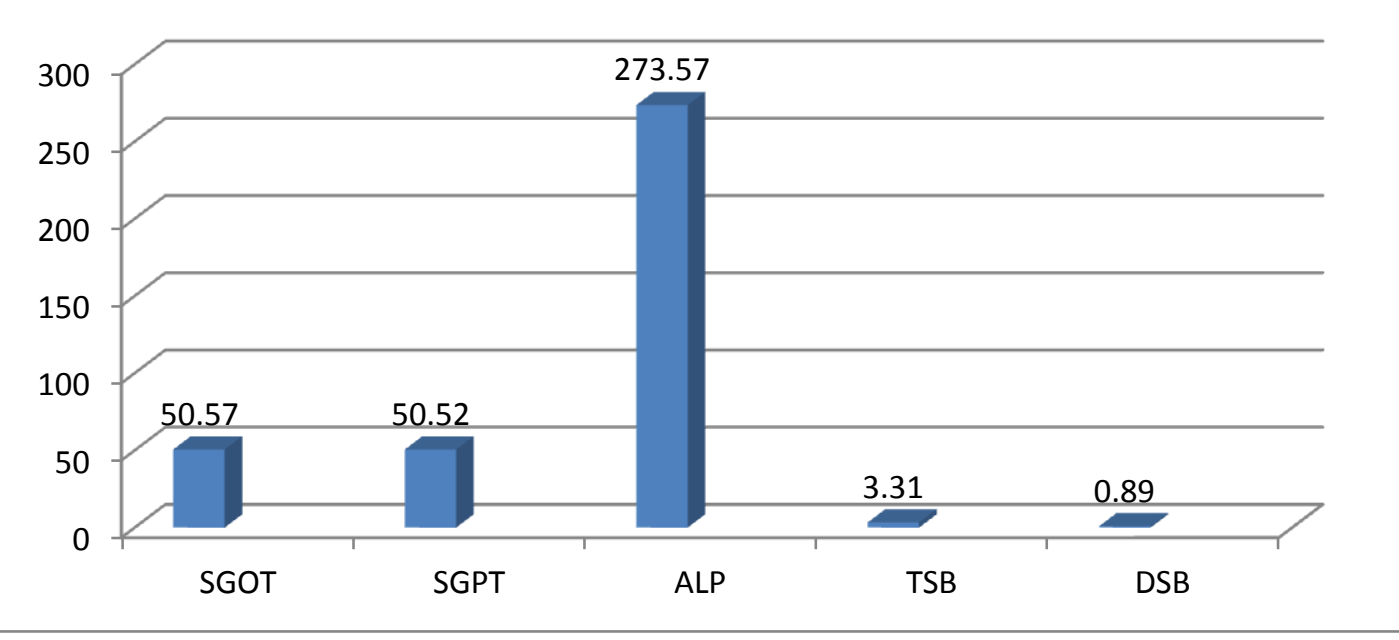

Fig 7: Distribution of Hepatic enzymes and Serum bilirubin (TSB \& Direct SB)

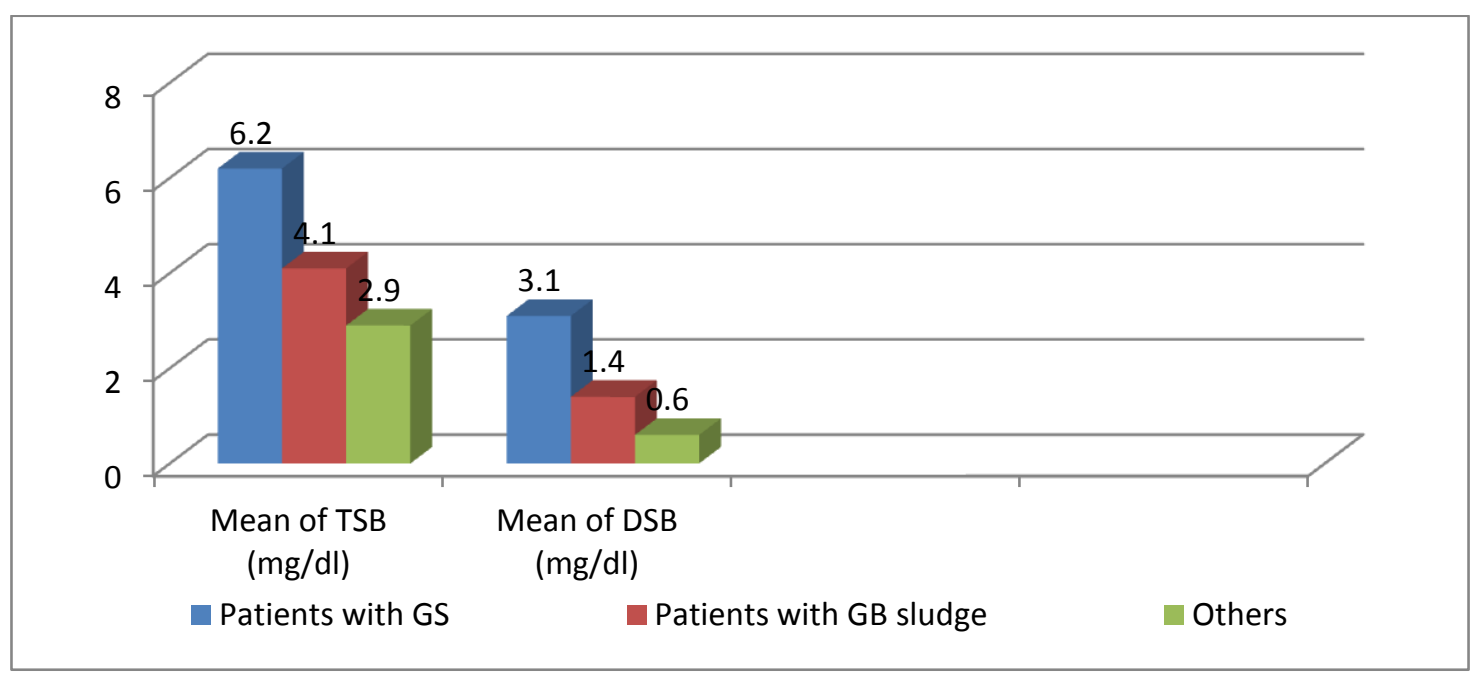

Fig 8 : Relation of bilirubin pattern with gallbladder pathology.

\section{Discussion}

This study was conducted at RIMS, Ranchi, Jharkhand; located in the tribal belt where sickle cell disease is prevalent and present work is to examine the sickle cell disease patients in respect of their high serum bilirubin pattern \& find a possible explanation in addition to determine the incidence of cholelithiasis.

Among 56 children of sickle cell disease, all homozygous (SS) have been studied. Most of the patients belonged to the age group 7-12 years. Least number of patients were in the age group 13-18 years because of increased rates of complication related mortality in this age group. These findings are consistent with the study done by Balgir, R. S. et al in $1999^{[2]}$. Male sex predominated the group by approximately $66 \%$, giving male:female ratio of 1.95: 1 .
In our study approximately $68 \%$ patients belonged to Hindu religion. Muslim patients bore almost $27 \%$ of the disease burden. Most of the muslim patients belonged to Ansari group and gave history of consanguineous marriage. Balgir, R. S. et al in $1996^{[3]}$ also found that consanguineous marriage further compound the complexity by increasing the homozygosity in the community.

Mean of reticulocyte count in the study was 6.67 and standard deviation of 1.4 with no significant differences in mean haemoglobin level and reticulocyte count in patients with or without cholestasis (similar to Rennel et al, 1984 ${ }^{[4]}$ and Sarnaik et al, $1980^{[5]}$ ). Firkin, F et al $1989^{[6]}$, found that reticulocytosis ranges between 5 and $10 \%$ in sickle cell anemia. Mean haemoglobin in this study was 7.02 with standard deviation of 1.04 . 
Hepatomegaly was present in all 56 cases with a maximum and minimum enlargement of $8 \mathrm{~cm} \& 2$ $\mathrm{cm}$ below right costal margin with mean hepatomegaly was $3.26 \mathrm{~cm}$ and standard deviation was 1.07. Bauer T.W. et al, $1980^{[7]}$ described hepatomegaly as one of the most constant findings in sickle cell anemia and its persistence as an index of severity of disease. Splenomegaly was found in 51 patients with maximum enlargement of $7 \mathrm{~cm}$ below left costal margin. 2 patients had splenectomy previously. 3 cases which had no palpable spleen belonged to13-18 years of age group. Repeated episodes of splenic infarcts and fibrosis could have been the cause of it.

Out of 18 patients in the age group 1-6 years, none had any gallbladder abnormality. Among 29 patients in the age group 7-12 years only 1 (3.45\%) had gallstone and 3 patients $(10.34 \%)$ had gallbladder sludge. There were 9 patients in the age group of 13-18 years, out of which 3 (33.33\%) had gallstone another 3 (33.33\%) had gallbladder sludge. This clearly indicates that as the age increases incidence of gallstone as well as gallbladder sludge increases. Out of total 56 patients only 4 had gallstones giving an overall incidence of $7.14 \%$. The youngest patient in our study with gallstone was 10 years old. There are reports of progressive age related increase in gallstones from $12 \%$ in patients aged 2-4 years to $43 \%$ in patients aged 15-18 years (Sarnaik et al,1980). In Jamaica, a study on randomly selected patients, indicated gallstones in $31 \%$ of patients aged 16-65 years (McCall et al, 1977 ${ }^{[8]}$ ). Another study including children from 2-18 years showed this incidence as $17 \%$ (Karayalcin et al, 1979 ${ }^{[9]}$ ). On the study of hepatobiliary system in our patients it was seen that the mean of SGOT was 50.57 and that of SGPT was 50.52 which were higher than normal. Mean of alkaline phosphatase was 273.57 and standard deviation of 133.57. Mean of total serum bilirubin was 3.31 and that of direct serum bilirubin was 0.89 which was again higher than normal. According to Rosenblate $\mathrm{H}$ $\mathrm{J}$,et al $1970^{[10]}$ in children, manifestations of sickle cell hepatopathy are mild and transient. These includes right upper quadrant pain, hepatomegaly, fever and leucocytosis, mild elevation of serum transaminase levels and moderate to marked elevation of serum bilirubin and alkaline phosphatase levels.

\section{Conclusion}

Sickle cell disease has been reported from all over the world including India. The early detection of high bilirubin pattern and cholelithiasis \& their treatment is essential for improving quality of life in sickle cell disease children. From our study it is concluded that -

1. In earlier age group, there was no differece among sickle cell patients regarding the any gallbladder abnormality but with increasing age there had been increasing incidence of gallstone as well as gallbladder sludge.

2. A low incidence of cholelithiasis (overall $7.14 \%$ ) in sickle cell disease patients of Jharkhand. The incidence of cholelithiasis and gallbladder sludge increases with age. Biliary sludge is best managed by serial ultrasound examinations at $12-24$ months interval unless cholestasis occurs. At that point, laparoscopic choleccystectomy is indicated. Elective laparoscopic choleccystectomy is done for symptomatic cholelithiasis and watchful waiting for asymptomatic (or minimally symptomatic) cholelithiasis.

3. It can be difficult to differentiate between abdominal pain due to gallstones from an abdominal crisis in sickle cell patient. Ultrasound should be performed in all children with sickle cell disease and abdominal pain before labeling them as having a sickle crisis

4. Sickle cell disease usually causes unconjugated hyperbilirubinemia but the episodes of conjugated hyperbilirubinemia do occur frequently, possibly due to sickle cell hepatic crisis, intrahepatic cholestasis, cholangitis, cholelithiasis or due to viral hepatitis. 


\section{JMSCR Vol||06||Issue||08||Page 1198-1204||August}

\section{References}

1. http://timesofindia.indiatimes.com/city/ran chi/10-of-tribals-afflicted - with - sickle cell anaemia / articleshow / 48037811.cms.

2. Balgir, R . S., Natl. Med. J.India, 1999, 12, 234-238.

3. Balgir, R .S., J.Assoc. Phys.India, 1996, 44, 25-28.

4. Rennels MB, Dunne MG et al: Cholelithiasis in patients with major sickle hemoglobinopathies. AJDC-Vol. 138, 6668, Jan 1967.

5. Sarnaik S, Slovis TL, Corbett DP et al: The cholelithiasis in sickle cell anaemia using the ultrasonic gray scale technique. J Pediatr 96 : 1005, 1980.

6. Firkin, F., Chesterman, C., Penington, D. and Rush, B., De Gruchy's Clinical Hematology in Medical Practice, Blackwell Scientific Publications, Oxford, $1989,5^{\text {th }}$ edn, pp. $137-172$.

7. Bauer TW, Moore GW, Hutchins GM. The liver in sickle cell disease: A clinicopathological study of 70 patients. Am J Med. 1980; 69: 833-37.

8. Mac Call IW, Desai P et al: Cholelithiasis in Jamaican patients with homozygous SCD, Am. J. Hemt. 3:15-31(1977).

9. Karayalcin G, Hassani N: Cholelithiasis in children with SCD, Am. J. Dis. Child, Vol. 133, 306-307, 1979.

10. Rosenblate $\mathrm{H} \mathbf{J}$ et al: The liver in sickle cell anaemia, Arch pathol lab med 1970; 90:235. 